\title{
Pepper and Onion Yield Estimate Parameters as Affected by Seed Treatment Options: In the Selected Districts of Central Rift Valley; Oromia Regional State of Ethiopia
}

\author{
M. Teshome-Abdissa' ${ }^{1}$ 0. Feyissa-Begna ${ }^{2}$, B. Abnet-Dereje ${ }^{1}$ \\ ${ }^{1}$ Jimma University College of Agriculture and Veterinary Medicine CASCAPE ${ }^{*}$ Project, Jimma, Ethiopia \\ ${ }^{2}$ Adami Tulu Agricultural Research Center, Zeway, Ethiopia \\ Email: degituabdissa@gmail.com
}

Received 21 January 2015; accepted 6 February 2015; published 10 February 2015

Copyright (C) 2015 by authors and OALib.

This work is licensed under the Creative Commons Attribution International License (CC BY). http://creativecommons.org/licenses/by/4.0/ (c) (i) Open Access

\section{Abstract}

Pepper and onion yield estimate parameters were conducted during off-season of 2011 using irrigation both at on-station and at on-farm of Adami Tulu Agricultural Research Center and its surrounding districts of Adami Tulu, Dugda and Bora district of central rift valley by participating important influential actors (farmers, NGOs, DAs, district agricultural officers, etc.) from the inception to evaluate different seed treatment options that can favor onion and pepper yield estimate parameters. Bombey red and Marekofana of high yielding, disease tolerant, early maturing, market and farmer preferred varieties were used for the research by collecting from Adami Tulu Agricultural Research Center. Data on performance of yield estimate parameters were evaluated until it was transferred to permanent field. The on-station data analysis result indicated that except root length and greenness of onion and seedling thickness and greenness of pepper, majority of yield estimate parameters were statistically $(P<0.05)$ significant while root length, shoot length and shoot height of onion on-farm were statistically $(P<0.05)$ non-significant. For on-station onion, hot water treatment supplemented with dressing the seed with half recommendation rate of apron-star resulted in the highest yield estimate parameters for most of the variables collected. Although there was an absence of consistent for all traits under analysis, sowing seed without any treatment resulted to the lowest count or measurement. But seed treated with mancozeb as per the recommendation gave the highest score or count for pepper except that of leaf number and greenness in which hot water treatment alone resulted in highest count. Even though yield estimate parameters don't totally reflect actual attainable yield at the end of harvesting, seedlings that were superior for those traits mostly reflect yield if different management options applied as per recommendation set for the crops.

${ }^{*}$ Capacity building for scale up of evident based best practice in agricultural production in Ethiopia.

How to cite this paper: Teshome-Abdissa, M., Feyissa-Begna, O. and Abnet-Dereje, B. (2015) Pepper and Onion Yield Estimate Parameters as Affected by Seed Treatment Options: In the Selected Districts of Central Rift Valley; Oromia Regional State of Ethiopia. Open Access Library Journal, 2: e1243. http://dx.doi.org/10.4236/oalib.1101243 


\title{
Keywords
}

\section{Seed, Chemicals, Hot Water, Growth Parameters, Onion and Pepper}

\author{
Subject Areas: Agricultural Science, Biotechnology
}

\section{Introduction}

Central rift valley area of East Shewa Zone is among the known producers and suppliers of tropical vegetables like tomato, onion, cabbage, hot pepper and green beans because of suitable edaphic and environmental conditions. However, the production and productivity have been declining because of different biotic stresses and bacterial disease of vegetable crops, like bacterial leaf spot of pepper caused by Xanthomonas campestris pv. Vesicatoria, bacterial canker of tomatoes (Clavibacteria michiganensis pv. Michiganensis) and black rot on cool crops (Xantomonas campestris pv. Campestris), which have become all too common in recent years. Over $90 \%$ of the Connecticut pepper plantings inspected over the last five years were infected with bacterial leaf spot that always drastically reduced profit and sometimes resulted in complete crop failure. One of the ways plant pathogens are introduced into a crop is on seeds. Among them, bacterial pathogens are particularly notorious. In general, the earlier a pathogen comes in contact with the crop, the greater the potential for a serious disease problem to develop. This is the reason why it is very important to start with "clean" seed. Clean seed can be obtained by applying one of the treatments described below to kill bacterial pathogens on and/or within the seed [1].

Successful vegetable crop production and optimum yields can be obtained only when maximum stand establishment is achieved. Stand reduction generally results in yield reduction and variable produce quality. Several factors contribute to stand establishment in the production of vegetable crops. Among which environmental factors (soil, temperature, etc.) as well as pathogens that attack seed and seedlings are the major one [2].

Pre-sowing seed treatment can help to optimize stand density that leads higher yield. Chemicals are applied to seed for a number of reasons, such as improving physical properties of the seed for ease of handling, reducing pesticide dusts used on seed. Such chemicals can be better protection against disease and biological controls to be added to the surface of the seed [3].

In history different tomatoes and onion variety were produced for long period of time in this central rift valley of Ethiopia, so this disease or insect pest was developed by these long production periods in the soil by crop re-use buried in the soil for long period of production. Nowadays, those disease or insect pests are making the crop unproductive in central rift valley. To cope up with those problems, the main producers of vegetables in Central Rift Valley of East Shewa Zone use high amounts of seeds per a unit area of land beyond a recommended seeding rate set by research centers for seed with good germination capacity (personal observation).

Since the seed is attributed with different seed born diseases, farmers make high investment to purchase chemicals to control those pests. Therefore, with the current escalating price of vegetable seed and agrochemicals that used to control disease and insects pests, it was high time to search available options to improve seedling, viability and field performance of the crops [4]. According to many scholars, hot water treatments and anti-fungal agrochemical dressing reduced the load of disease that might reduce production cost of tropical vegetables like onion and pepper. But there is no or little information available on different anti-fungal agrochemical chemicals supposed to reduce disease load by mixing with hot water. Therefore, the research was conducted with the objectives of:

- To evaluate different seed treatment options that can improve field survival rate of onion and pepper.

- To create awareness for actors involved in production and dissemination of onion and pepper with the different technological options.

\section{Material and Methods}

\subsection{Description of the Study Area}

The experiment was conducted in the Central Rift Valley, East Shewa Zone in the three selected districts (Adami Tulu, Dugda and Bora) known for production and suppliers of tropical vegetables including onion and pepper to nearby big cities like Hawasa, Addis Ababa and Adama. In the districts most of the farm lands has been uti- 
lized for vegetable production that might be because of location advantage, suitability of edaphic and environmental condition, and accessibility of fresh water from Lake Zeway, Awash and Koka.

\subsection{Treatments}

T1: Dressing seed with Apron star as recommendation set for the crop.

T2: Dressing the seed with mancozeb as per the recommendation.

T3: Immersing the seed with hot water at $50^{\circ} \mathrm{C}$ for 10 minutes.

T4: Boiling seed with hot water at $50^{\circ} \mathrm{C}$ for 10 minutes and dressing with Apron star with half of the recommendation.

T5: Boiling the seed with hot water at $50^{\circ} \mathrm{C}$ for 10 minutes and dressing with mancozeb with half of the recommendation.

T6: control (farmers practice).

Those six treatments were used for both onion and tomato to reduce the load of seed born that resulted to pre and post-harvest losses of the two commodities.

Following the treatment, representative sample of 100 - 150 seed was planted on Petri dish to evaluate their germination by replicating four times in germination champers. The germinated number was counted from the first date of germination till the expected time of completion. The result indicated the germination potential of the two commodities were promising and falls in acceptable range of ( $85 \%$ to $90 \%$ ). Then it was planted both on farm and on station by following the full agronomic packages as per the recommendation set for the crop. The treatments were laid out as Randomized Complete Block Design (RCBD) with three replications at on-station and single observation plot at on farm. One representative and potential PA (peasant association) was selected from each of the tree district. Those PA's were selected based on accessibility to the main road for regular monitoring, potential production of those crops in bulk amount, existence of already established farmers research group. Those three PAs were taken as a replication to handle diversities came from biotic and a biotic factors.

\subsection{Different Variables on Which Data Collected}

Data were collected at 55 days of seed sowing in nursery (at the time of transplanting to permanent field) on seedlings shoot height $(\mathrm{cm})$, leaf length $(\mathrm{cm})$, shoot thickness $(\mathrm{cm})$, tap root length $(\mathrm{cm})$, greenness scored as $(1$ = deep yellow; 2 = yellow; $3=$ light yellow; $4=$ green; $5=$ very green $)$ seedling vigrousity scored as $(1=$ very low vigor; 2 = low vigor; 3 = vigor; 4 = highly vigor; 5 = very highly vigor), count of average leaf number per plant and shoot length $(\mathrm{cm})$. All the collected data were analyzed with SAS 2000 software version 8.0 for the statistically significant variables, mean separation was made using fisher least significant difference at $(\mathrm{P}<$ $0.05)$.

\section{Results and Discussion}

\subsection{Participatory Research Approach Viewed as Technology Adoption}

In the past Ethiopian research system participating farmers in technology generation was not done as expected. That resulted shelving of research out comes done at on research station. Feed backs collected from farmers by different scholars' revealed traits desired by farmers are much more different than that of yield increments reported by researchers. Nowadays participating farmers in technology generation and evaluation as well handling their indigenous knowledge and feedback got due attention. As reported by [5] currently the government of Ethiopia set an strategy of research development by involving the important key actors like farmers, local and international NGOs working with and for farmers, Ministry of Agriculture, DA's etc. who have direct and indirect contribution for the ultimate technology generation and adoption.

Five farmers including respective district SMS (Subject Matter Specialist) and DA working in those PA were invited to the center for the training at Adami Tulu Agricultural Research Center. They were trained by multidisciplinary team of researchers' with issues like important disease and their yield losses in vegetable crops at the central rift valley of East Shewa Zone with their pictorial presentation, different seed treatments options that can really reduce seed born disease of (onion and pepper), role and responsibility sharing among actors were made. 


\subsection{On-Station Onion Yield Estimate Parameters as Affected by Seed Treatment Options}

\subsubsection{Vigourousity, Seedling Height, Leaf Length and Seedling Thickness of Onion as Affected by Seed Treatments Option}

The above four parameters were statistically affected by those treatments at $\mathrm{P}<0.05$ (Table 1). Hot water treatment with half of the apron star recommendation resulted with the highest vigorosity (3.6) followed by apron star as per the recommendation (3.00) while the hot water treatment alone resulted to the lowest vigor development of the seedling. Similar to the vigrousity, hot water treated with half of apron star recommendation resulted to the highest seedling height $(20.80 \mathrm{~cm})$ and it is statistically significant with that of control and hot water treated with half of mancozeb as per recommendation while it was in statistically parity with the rest treatments.

In conformity with the above two parameters leaf length and seedling thickness also benefited and became statistically significant with hot water treated with half of apron star while the lowest was observed with control indicating the contribution of the hot water and apron-star to counter act seed born biotic stresses that negatively influence onion yield estimate parameters.

\subsubsection{Root Length, Leaf Number; Shoot Length and Greenness of Onion as Affected by Seed Treatments Option}

As opposed to the most onion yield estimate parameters, average root length of onion resulted to statistically non-significant at $(\mathrm{P}<0.05)$. This result is corroborated by those of [6] who reported that as side of seed treatments by different chemicals and hot water, tomato seedlings benefited from different soil media like farmyard manure, termite tomb, coarse sand and red ash were used to make ideal soil conditions, that provides good aeration and better water holding capacity at Adami Tulu areas. Even though it is in statistical parity with that of hot water, hot water with that half recommendation of apron star resulted with the highest leaf number (3.73). In contradictory with most of onion yield estimate parameters, control (seed sowing without any treatment) resulted to the highest shoot length $(4.60 \mathrm{~cm})$ and it is statistically significant at $(\mathrm{P}<0.05)$ while the current result revealed non-significant variation for onion leaf greenness. Even though it was statistically insignificant and parity with the other treatment options, treating the seed with apron star as per the recommendation was $49.8 \%$ and $39.9 \%$ more green than that of hot water and mancozeb as per the recommendation respectively that resulted to yellow onion leaf color. This indicated though most of onion yield estimate parameters were benefited from hot water treated with half of apron star recommendation, dressing the seed with apron star as per the recommendation resulted to deep green color of onion that is sufficient with chlorophyll pigment that helped the plant to intercepts photo synthetically active radiation from which the plant synthesize its own assimilate.

\subsection{On-Station Pepper Yield Estimate Parameters as Affected by Seed Treatment Options}

Among those five parameters collected for pepper, vigrousity, seedling height and seedling thickness highly

Table 1. Response of on-station onion yield estimate parameters for 2011 cropping season.

\begin{tabular}{|c|c|c|c|c|c|c|c|c|}
\hline Treatments & Vigrousity & $\begin{array}{c}\text { Seedling } \\
\text { height }\end{array}$ & $\begin{array}{c}\text { Leaf } \\
\text { length }\end{array}$ & $\begin{array}{l}\text { Seedling } \\
\text { thickness }\end{array}$ & $\begin{array}{l}\text { Root } \\
\text { length }\end{array}$ & $\begin{array}{c}\text { Leaf } \\
\text { number }\end{array}$ & $\begin{array}{l}\text { Shoot } \\
\text { length }\end{array}$ & Greenness \\
\hline ASR & $3.00 \mathrm{ab}$ & 20.23 a & $15.77 \mathrm{ab}$ & $0.22 \mathrm{~b}$ & $3.25 \mathrm{a}$ & $3.00 \mathrm{bc}$ & $4.56 \mathrm{ab}$ & 3.33 a \\
\hline MR & $2.33 \mathrm{bc}$ & $17.07 \mathrm{ab}$ & 13.37 bc & $0.20 \mathrm{~b}$ & $2.37 \mathrm{a}$ & $2.43 \mathrm{bc}$ & $3.97 \mathrm{ab}$ & $2.00 \mathrm{a}$ \\
\hline HW & 1.67 c & $16.67 \mathrm{ab}$ & $12.33 \mathrm{c}$ & $0.27 \mathrm{~b}$ & $2.96 \mathrm{a}$ & 3.26 abc & $3.73 \mathrm{ab}$ & $1.67 \mathrm{a}$ \\
\hline ASHW & 3.67 a & 20.80 a & $16.82 \mathrm{a}$ & $0.31 \mathrm{a}$ & $4.00 \mathrm{a}$ & 3.73 a & $4.03 \mathrm{ab}$ & $2.67 \mathrm{a}$ \\
\hline MHW & $2.33 \mathrm{bc}$ & $14.87 \mathrm{~b}$ & $11.60 \mathrm{c}$ & $0.24 \mathrm{ab}$ & $3.60 \mathrm{a}$ & $3.33 \mathrm{~b}$ & $3.23 \mathrm{~b}$ & $2.67 \mathrm{a}$ \\
\hline $\mathrm{C}$ & $2.67 \mathrm{~b}$ & $18.00 \mathrm{~b}$ & 13.36 bc & $0.17 \mathrm{~b}$ & $2.30 \mathrm{a}$ & $2.67 \mathrm{c}$ & $4.60 \mathrm{a}$ & 2.33 a \\
\hline F-test & $* *$ & ** & $* *$ & $* *$ & NS & ** & $* *$ & NS \\
\hline LSD (0.05) & 0.92 & 4.97 & 3.34 & 0.077 & 1.74 & 0.63 & 1.36 & 1.81 \\
\hline $\mathrm{CV}$ & 19.36 & 15.26 & 13.23 & 18.56 & 31.02 & 11.13 & 18.66 & 40.68 \\
\hline
\end{tabular}

Key: ASR = apron star as recommendation; MR = mancozeb as recommendation; HW = hot water; ASHW = 1/2 apron star with hot water; MHW = $1 / 2$ mancozeb with hot water; $\mathrm{C}=$ control; NS = non-significant; ${ }^{* *}$ Highly significant; LSD = least significant difference; CV = coefficient of variation. Greenness: 1 = deep yellow; 2 = yellow; 3 = light yellow; 4 = green; 5 = very green. Vigrousity: 1 = very low vigor; $2=$ low vigor; $3=$ vigor; 4 $=$ highly vigor; 5 = very highly vigor. 
responsive and resulted to the highest yield estimate parameters with mancozeb dressing as per the recommendation while hot water resulted to the highest count and score for leaf number and greenness respectively (Table 2) as opposed to onion that is highly responsive to hot water treatment supplemented with dressing with apron star with half the recommendation, mancozeb dressing as per the recommend rate resulted to significant yield estimate parameter of pepper. This result indicated that different commodities are responsive to different seed treatment options calling for independent research findings to avoid hast generalization.

\subsection{On-Farm Onion Yield Estimate Parameters as Affected by Seed Treatments Options}

\subsubsection{Average Root Length}

The analysis of variance didn't indicate statistically significant $(\mathrm{P}<0.05)$ variation for this parameter of onion in response to different treatment options. However, treating with apron star as per the recommendation set for the crop resulted to $24.93 \%$ root length increment than that of half apron star with hot water treated treatments (Table 3). According to [6] since onion is shallow rooted plant any treatments that can lead to increase the root benefit the plant because of easily accessed to soil moisture and nutrients especially in arid and semi-arid areas similar to where the current research activity was conducted.

\subsubsection{Average Leaf Number and Shoot Length of Onion as Affected by Different Seed Treatments} From the current study onion leaf number per plant was highly affected by the treatments and it was statistically significant at $\mathrm{P}<0.05$ (Table 1 ). The number of leaf developed by a given plant is correlated with the amount of Photo-synthetically active radiation that has been used to produce assimilates; any treatment that favors the production of healthy leaf is positively correlated to the yield. From the result of (Table 2), seed treated with mancozeb as the recommendation set was highly performed though it was statistical parity with the rest treatments except that of apron star at $\mathrm{P}<0.05$ that resulted to the lowest leaf number per plant.

Shoot length was non-significantly affected by those treatments at $\mathrm{P}<0.05$. Even though it is non-significant with the other treatments, the highest shoot length $(7.47 \mathrm{~cm})$ was recorded in seed treated by half mancozeb with that of hot water. Evidently the lowest $(6.67 \mathrm{~cm})$ was recorded with that of control. From the above all parameters even though there was absence of consistent difference among the treatments the growth parameter were benefited from the treated seeds.

According to [7] and [8] although not always consistently, fungicide seed treatments have been shown to provide protection to soybean against stand or yield reductions caused by seedling diseases in certain instances.

\subsection{Shoot Height, Leaf Length and Shoot Thickness as Affected by Different Seed Treatments}

Leaf length and shoot thickness were statistically $(\mathrm{P}<0.05)$ affected by those seed treatment options, while shoot height was non-significantly affected (Table 4). Those above yield estimate parameters increased with treatment with hot water except that of mancozeb in average leaf length that is statistically parity with hot water.

Table 2. Response of on-station pepper yield estimate parameters for the year 2011 cropping season.

\begin{tabular}{|c|c|c|c|c|c|}
\hline Treatments & Vigrousity & Seedling height & Seedling thickness & Leaf number & Greenness \\
\hline ASR & $3.47 \mathrm{ab}$ & $24.90 \mathrm{a}$ & 0.19 a & $9.20 \mathrm{~b}$ & $2.87 \mathrm{a}$ \\
\hline MR & 3.93 a & $22.13 \mathrm{a}$ & $0.21 \mathrm{a}$ & $11.20 \mathrm{ab}$ & $3.60 \mathrm{a}$ \\
\hline HW & $3.33 \mathrm{ab}$ & $16.33 \mathrm{~b}$ & $0.20 \mathrm{a}$ & $12.80 \mathrm{a}$ & $3.73 \mathrm{a}$ \\
\hline ASHW & $2.80 \mathrm{~b}$ & $15.33 \mathrm{~b}$ & $0.21 \mathrm{a}$ & $12.27 \mathrm{a}$ & $3.00 \mathrm{a}$ \\
\hline MHW & $2.80 \mathrm{~b}$ & $13.92 \mathrm{~b}$ & $0.17 \mathrm{a}$ & $10.87 \mathrm{ab}$ & $2.97 \mathrm{a}$ \\
\hline $\mathrm{C}$ & $3.20 \mathrm{ab}$ & 20.93 a & $0.16 \mathrm{a}$ & $11.00 \mathrm{ab}$ & $3.33 \mathrm{a}$ \\
\hline F-test & $* *$ & ** & NS & ** & NS \\
\hline LSD (0.05) & 0.91 & 4.09 & 0.057 & 2.52 & 1.37 \\
\hline $\mathrm{CV}$ & 15.31 & 11.82 & 16.53 & 12 & 23.11 \\
\hline
\end{tabular}

Key: ASR = apron star as recommendation; MR = mancozeb as recommendation; HW = hot water; ASHW = 1/2 apron star with hot water; NS = non-significant; ${ }^{* *}$ Significant; MHW = 1/2 mancozeb with hot water; C = control; LSD = least significant difference; CV = coefficient of variation. Greenness: 1 = deep yellow; 2 = yellow; 3 = light yellow; 4 = green; 5 = very green. Vigrousity: $1=$ very low vigor; 2 = low vigor; 3 = vigor; 4 = highly vigor; 5 = very highly vigor. 
Table 3. Response of onion growth parameter to the application of different seed treatment options.

\begin{tabular}{cccc}
\hline Treatments & Root length $(\mathrm{cm})$ & Leaf number & Shoot length $(\mathrm{cm})$ \\
\hline ASR & $3.73 \mathrm{a}$ & $2.80 \mathrm{~b}$ & $7.40 \mathrm{a}$ \\
MR & $3.52 \mathrm{a}$ & $3.93 \mathrm{a}$ & $6.87 \mathrm{a}$ \\
HW & $3.27 \mathrm{a}$ & $3.60 \mathrm{ab}$ & $7.33 \mathrm{a}$ \\
ASHW & $2.80 \mathrm{a}$ & $3.47 \mathrm{ab}$ & $7.47 \mathrm{a}$ \\
MHW & $3.17 \mathrm{a}$ & $3.60 \mathrm{ab}$ & $7.27 \mathrm{a}$ \\
C & $3.60 \mathrm{a}$ & $3.47 \mathrm{ab}$ & NS \\
F-test & NS & $* *$ & 2.16 \\
LSD (0.05) & 1.248 & 0.99 & 16.54 \\
CV & 20.49 & 14.91 & \\
\hline
\end{tabular}

Key: ASR = apron star as recommendation; NS = non-significant; ${ }^{* * *}$ Significant; MR $=$ mancozeb as recommendation; HW $=$ hot water; ASHW $=1 / 2$ apron star with hot water; MHW = 1/2 mancozeb with hot water; C = control; LSD = least significant difference; CV = coefficient of variation.

Table 4. Response of onion growth parameter to the application of different seed treatment options.

\begin{tabular}{cccc}
\hline Treatments & Shoot height $(\mathrm{cm})$ & Leaf length $(\mathrm{cm})$ & Shoot thickness $(\mathrm{cm})$ \\
\hline ASR & $30.23 \mathrm{a}$ & $23.80 \mathrm{~b}$ & $0.31 \mathrm{~b}$ \\
MR & $35.00 \mathrm{a}$ & $28.37 \mathrm{a}$ & $0.44 \mathrm{ab}$ \\
HW & $35.47 \mathrm{a}$ & $28.20 \mathrm{a}$ & $0.48 \mathrm{a}$ \\
ASHW & $33.23 \mathrm{a}$ & $26.10 \mathrm{ab}$ & $0.35 \mathrm{ab}$ \\
MHW & $32.37 \mathrm{a}$ & $25.17 \mathrm{ab}$ & $0.38 \mathrm{ab}$ \\
C & $31.73 \mathrm{a}$ & $25.30 \mathrm{ab}$ & $0.40 \mathrm{ab}$ \\
F-test & NS & $* *$ & 0.148 \\
LSD (0.05) & 5.61 & 4.37 & 20.72 \\
CV & 9.34 & 9.19 & $*$ \\
\hline
\end{tabular}

Key: ASR = apron star as recommendation; MR = mancozeb as recommendation; HW = hot water; ASHW = 1/2 apron star with hot water; MHW = half mancozeb with hot water; $\mathrm{C}=$ control; $\mathrm{LSD}=$ least significant difference; $\mathrm{CV}=$ coefficient of variation.

From the above yield estimate parameters, even though there were clear responses of some growth parameters to those treatments, it is too early to recommend the treatments. From the research findings of [6] effect of seedling management on yield and quality of tomato at Adami Tulu District, there were non-significant yield difference at the time of harvesting even though there were variation growth parameters in response to different soil media utilization.

\section{Acknowledgements}

I express my heartfelt appreciation to JICA-FRGII for their fund support and also all horticulture staffs of Adami Tulu Agricultural research center specially (Abebe Temesgen, Fiseha Tadesse and Ayana Itana) who had been involved in data collection, monitoring as well as training of farmers and other stakeholders. Lastly I would like to thank my beloved wife Lalise for her encouragement and support during the period write up.

\section{References}

[1] Boucher, J. and Nixon, G. (1995) University of Connecticut Cooperative Extension System, Ruth Hazard and Robert Wick. University of Massachusetts Cooperative Extension System Preventing Bacterial Disease of Vegetables with Hot-Water Seed Treatment, 3.

[2] Orzolek, M.D. (1991) Establishment of Vegetables in the Field. Hort Technology, 1, 78. http://www.hort.uconn.edu/ipm/

[3] Bennett, M., Fritz, V.A. and Callan, N.W. (1992) Impact of Seed Treatments on Crop Stand Establishment. Hort Technology, 2, 345. http://www.hort.uconn.edu/ipm/

[4] Pratap, N. (2006) Question Bank on Agriculture for Competitive Exams. 3rd Revised and Enlarged Edition, International Book Distribution Co., 891. 
[5] Abdissa, T., Chali, A., Tolessa, K., Tadese, F. and Awas, G. (2011) Yield and Yield Components of Sweet Potato as Influenced by Plant Density: In Adami Tulu Jido Kombolcha District, Central Rift Valley of Ethiopia. American Journal of Experimental Agriculture, 1, 40-48. http://dx.doi.org/10.9734/AJEA/2011/173

[6] Abdissa, T., Chali, A., Hawas, G. and Mume, T. (2010) Effect of Seedling Management on Yield and Quality of Tomato at Adami Tulu Jiddo Kombolcha District, Central Rift Valley of Ethiopia. African Journal of Agricultural Research, 5, 3056-3059.

[7] Bradley, C.A., Wax, L.M., Ebelhar, S.A., Bollero, G.A. and Pedersen, W.L. (2001) The Effect of Fungicide Seed Protectants, Seeding Rates, and Reduced Rates of Herbicides on No-Till Soybean. Crop Protection, 20, 615-622. http://dx.doi.org/10.1016/S0261-2194(01)00057-6

[8] Dorrance, A.E., Kleinhenz, M.D., McClure, S.A. and Tuttle, N.T. (2003) Temperature, Moisture, and Seed Treatment Effects on Rhizoctonia solani Root Rot of Soybean. Plant Disease, 87, 533-538. http://dx.doi.org/10.1094/PDIS.2003.87.5.533 
Scientific Research Publishing (SCIRP) is one of the largest Open Access journal publishers. It is currently publishing more than 200 open access, online, peer-reviewed journals covering a wide range of academic disciplines. SCIRP serves the worldwide academic communities and contributes to the progress and application of science with its publication.

Other selected journals from SCIRP are listed as below. Submit your manuscript to us via either submit@scirp.org or Online Submission Portal.
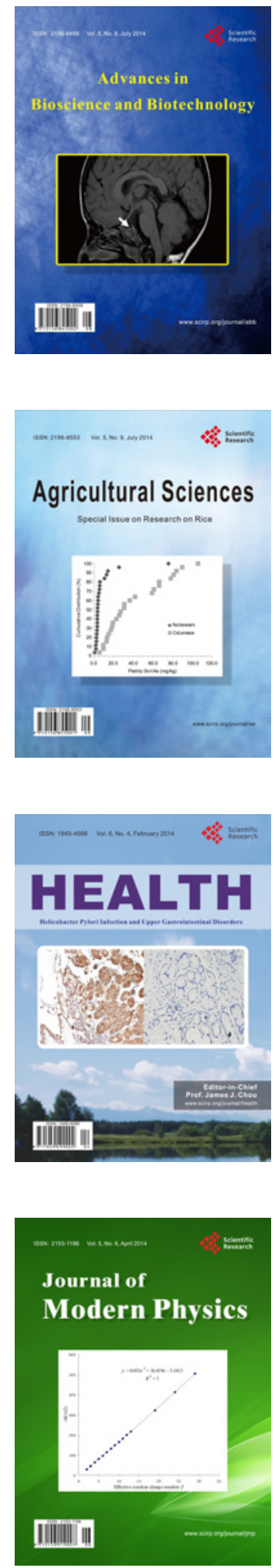
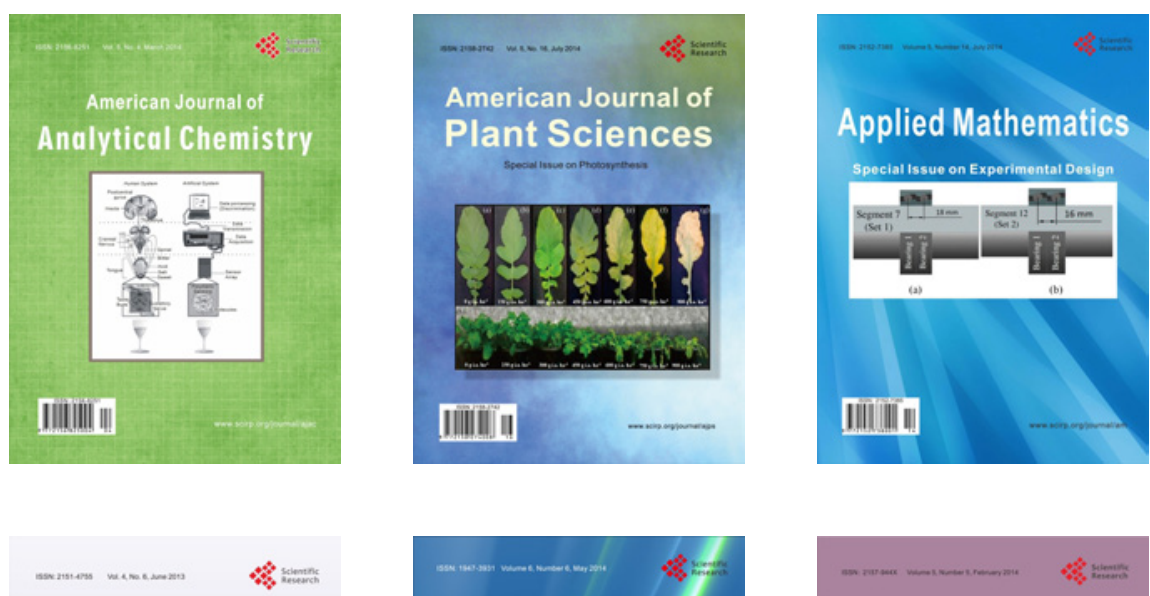

Creative Education
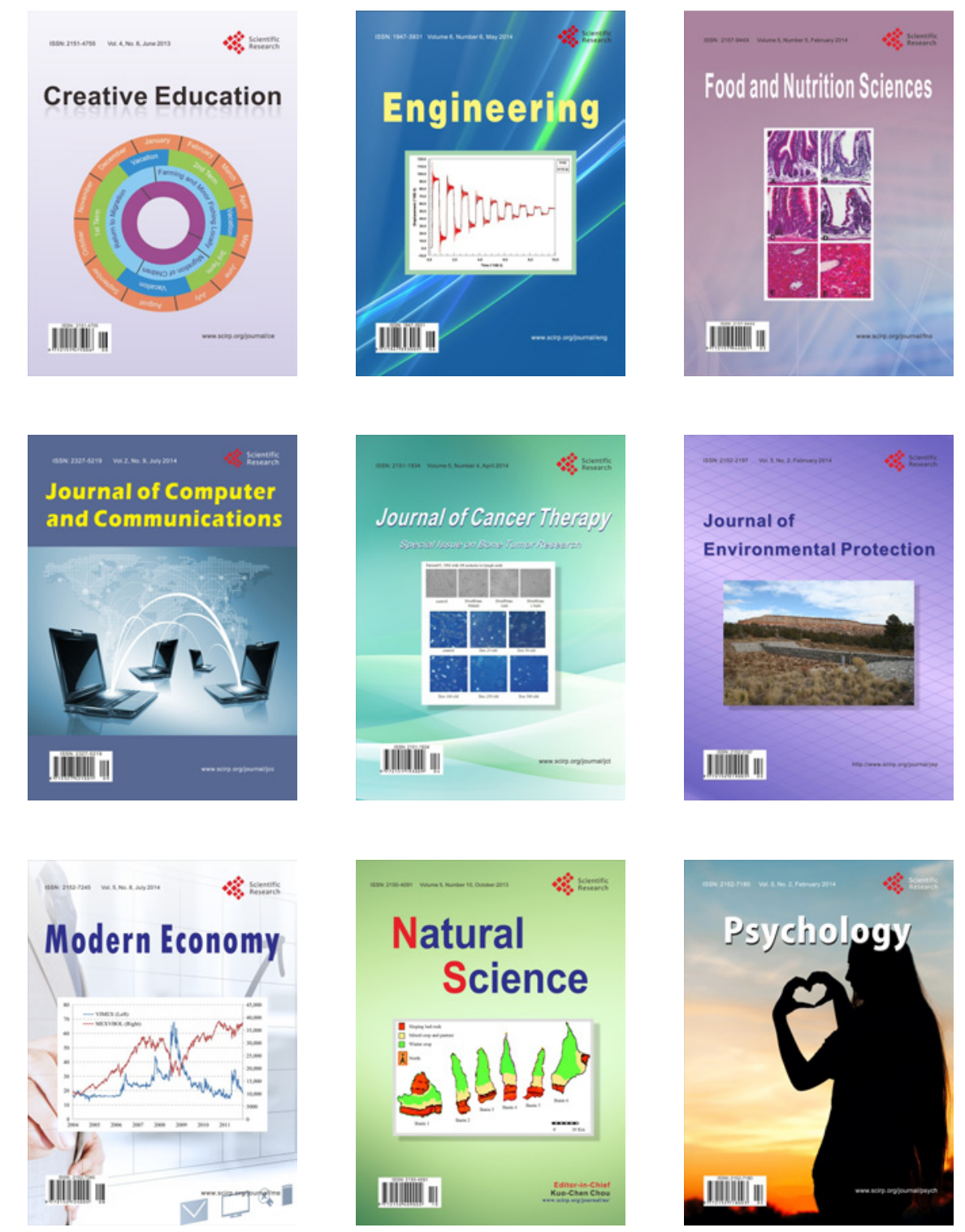